\title{
A Química e a Arte
}

PEDRO REDOL

0 MAIOR RISCO QUE COMPORTA A ABORDAGEM da realidade desde um ponto de vista profissional especializado é justamente o de se perder o sentido mais profundo dessa realidade. Em contrapartida, reflexões muito abrangentes caem com demasiada facilidade em lugares comuns. Desta forma, a descoberta de caminhos novos e úteis depende, em grande medida, do desenvolvimento de aptidões particulares para avaliar e confrontar experiências efectivas bastante diversas de apropriação do real.

Aquilo que a sistematização filosófica referente às culturas do Ocidente designou por arte, separando-a da religião e da ciência, parece ser o modo de apropriação do real e de ordenamento do mundo que melhor conserva a essência ancestral do saber: abordagem sensorial/intelectual, mediada pela técnica e projectada em expressões de intercessão quase mágica junto das causas do devir. Como tal são-Ihe reconhecidas virtualidades terapêuticas no tratamento da neurose civilizacional provocada pela separação de modos de apropriação do real outrora indiferenciados. A relação dialéctica percepção/elaboração artística acabou por ser justamente considerada um dado inextricável da natureza humana e um motor privilegiado da sua estruturação ética.

O património do saber secularmente construído - que engloba o património artístico - é outro dado fundamental do conhecimento, uma vez que este parte indefectivelmente de referências culturais pré-existentes para fazer o seu caminho, através de mecanismos de acomodação, assimilação e ruptura. Para se transmitir, qualquer património conta com a memória correspondente e, em muitos casos, com o seu próprio suporte material. No entanto, a transmissão de todo o saber é apenas justificada pela sua auto-ultrapassagem.

Em particular, a perda acelerada de referências nas culturas pós-modernas veio conferir ao património artístico uma centralidade sem precedentes. $E$ assim surgem as chamadas ciências do património, entre as quais se contam as que se ocupam da sua preservação e reabilitação. Assim surge também a chamada indústria do património cultural.

A emergência de horizontes epistemológicos específicos do património artístico criou a expectativa de interfaces privilegiadas entre domínios do conhecimento estabelecidos e separados de longa data, em particular entre as ciências humanas e as ciências da natureza. Esperava-se o nascimento de um homem novo, na confluência destes saberes e na sua operacionalização/ /questionamento através das adequadas técnicas. Persiste ainda a expectativa, perante a realidade incontornável de que a devolução do património artístico ao devir estético é condição essencial para a sua sobrevivência.

Neste contexto, a química assume um papel que facilmente se adivinha. Do ponto de vista do suporte material das obras de arte, ela ajuda a entender os respectivos métodos de produção, a sua natureza e os correspondentes mecanismos de alteração. Semelhante entendimento permite, por sua vez, esperar a criação e a adaptação de métodos de tratamento e protecção adequados a cada caso.

A química, em si mesma, deriva do desejo antigo de conhecer os ingredientes da matéria para os combinar da forma mais proveitosa. É legítima, no entanto, a curiosidade inerente, que justifica a existência de uma ciência de direito próprio, onde o conhecimento é sentido como uma necessidade per se, independentemente da sua operatividade tecnológica. Neste contexto, é importante assinalar que o estudo material de obras de arte pelos químicos satisfaz necessidades intelectuais efectivas, mas que, nem sempre, pode ter consequências reais sobre o património artístico.

Dado o interesse fulcral da química para todas as questões que se prendem com o suporte material das obras de arte pois o seu objecto de conhecimento são justamente as transformações sofridas pela matéria - é importante estabelecer com clareza, em cada contexto cívico, os objectivos do correspondente desempenho, não bastando para tal a clássica distinção entre pesquisa fundamental e pesquisa aplicada.

Desta ordem de ideias resulta não apenas que o interesse cultural da química deve ser definido em função dos objectivos científicos e/oủ patrimoniais a atingir, mas ainda que, em contexto de património artístico, se reveste de capital importância o desenvolvimento das suas capacidades específicas de diálogo, investindo os correspondentes esforços em projectos enquadrados por um entendimento dinâmico da conservação 
dos suportes artísticos. Semelhante enquadramento é da responsabilidade do conservador-restaurador, adequadamente preparado do ponto vista artístico, científico e tecnológico. Conforme tem vindo a ser notado, ao logo das últimas duas décadas, a soma de componentes qualificadas de formação desta ordem não é suficiente para construir o perfil do conservador-restaurador assim idealizado. A emergência de uma atitude narcísica em relação ao património artístico, esquecendo o carácter vital da sua auto-ultrapassagem, é a principal causa de desorientação no que se refere ao estabelecimento de prioridades de investigação. Na prática, o alargamento do objecto patrimonial (tudo é passível de ser património) torna impossível - e indesejável - a resolução de todos os problemas de conservação do respectivo suporte material. Não se trata somente de um problema de volume de tratamentos, mas também da emergência de infindáveis questões científicas, cujo interesse importa relativizar.
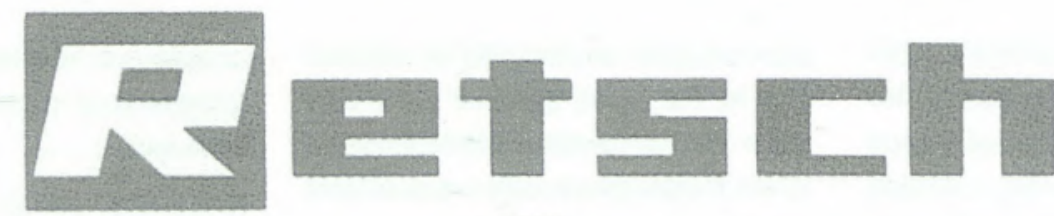

9001

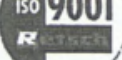

Moinhos

Agitadores de peneiros/peneiros
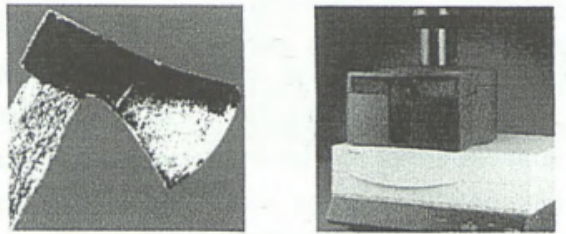

Divisores de amostras
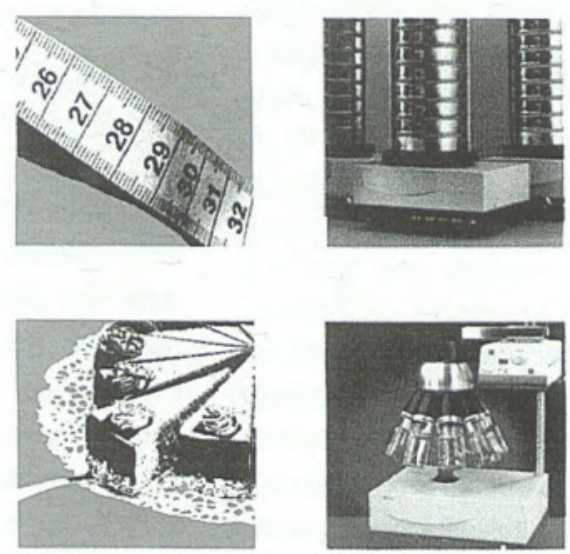

\section{Análise granulométrica automática CAMSIZER / CRYSTALSIZER}

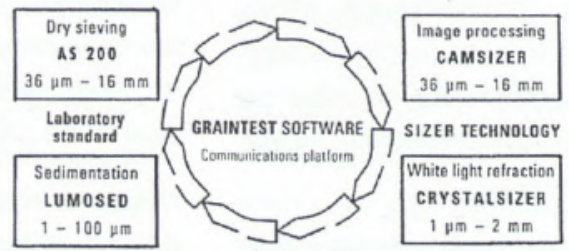

Peça-nos o contacto do agente mais próximo, através dos telefones:

21-352 7293

LISBOA
22-618 4232

\section{O Impartadar Exclusiua}

